Agro-Science Journal of Tropical Agriculture, Food, Environment and Extension Volume 19 Number 2 (Apr. 2020) pp. 6 - 12

ISSN 1119-7455

\title{
ECONOMICS OF PIGGERY ENTERPRISE IN NIGERIA: A CASE STUDY OF UDI LOCAL GOVERNMENT AREA OF ENUGU STATE, NIGERIA
}

\author{
Onyekuru N.A., *Ukwuaba I.C. and Aka E.O. \\ Department of Agricultural Economics, University of Nigeria, Nsukka, Enugu State, Nigeria \\ Corresponding author's email: ikenna.ukwuaba@unn.edu.ng
}

\begin{abstract}
The study examined the economics of pig enterprise in Udi Local Government Area of Enugu State, Nigeria. Despite the economic leverage and nutritional advantages of pig, its production still remains the least when compared to other livestock sub-sector. The study specifically described the socioeconomics characteristics of pig farmers, examined the factors influencing revenue from pig production, estimated the costs and returns in pig production and examined the problems faced by pig farmers in the area. Purposive and random sampling techniques were used in the selection of 60 farmers for the study. Primary data were collected from the selected farmers with the aid of structured questionnaire. Data were analysed using descriptive statistics, net income and multiple regression models. Results showed that majority of the respondents (85\%) were male, married (81.7\%), literate (100\%) with mean age and household size of 48 years and five persons, respectively. Majority (88.3\%) of the respondents sourced their capital from personal savings and $95 \%$ of them had crossed breeds of pigs. The determinants of net income from pig production were education $(-0.271)$, cost of feed (0.687) and cost of labour (0.329). The profitability and the viability of piggery enterprise in the study area were shown by the gross margin, net farm income and the return on investment of $\$ 824,395.30$ (\$2,269.56), \$747,797.42 (\$2,058.69) and 0.84 (84\%), respectively. Huge capital required for the investment, inadequate extension education, high cost of feed, diseases and parasite infestation, poor farm management, high cost of veterinary services, insufficient credit facilities and subsidies, and infant mortality and cannibalism were the major constraints faced by the farmers in the piggery enterprise. The study recommends that the government and other relevant agencies should provide subsidies and make credit facilities available and accessible to pig farmers in the study area.
\end{abstract}

Key words: pig production, enterprise, gross margin, profitability, Nigeria

\section{INTRODUCTION}

The lingering economic quagmire, coupled with an increasing population growth, low food production and continuous rising food demand in Nigeria have led to increasing cases of mal-nutritional diseases nationwide (Onah, 2015). This ugly development has necessitated a national consciousness and outcry for a tremendous improvement in animal protein production, availability, accessibility and affordability in the country. Therefore, food supply must be improved by all the concerned sectors, including the different value chains both in quantity, quality and proportionally distributed to enhance food security.

Pig (Sus scrofa), a monogastric animal, with its huge potential and profitability, remains a very lucrative livestock venture with a capacity of ameliorating the hunger problem and safeguard the future of the nation's food supplies as well as a veritable tool for curbing the increasing unemployment occasioned by the current economic downturn. The breeding and rearing of pigs for domestic and commercial purposes have gained more attention in recent time due to the rising demand, especially for dietary purpose; thus, creating more market for those in the piggery enterprise (National Agricultural Sample Survey, 2011).

The importance of pigs in the livestock industry in Nigeria cannot be over-emphasized. Although pigs represent about $4 \%$ of the total domestic livestock in Nigeria, they display a unique ability to adapt and survive in areas where they are found (Ajala et al., 2006). Some of these unique characteristics include but not limited to high survival rate, very good efficiency of feed utilization which brings better returns per units of inputs than most other livestocks, high prolificacy, having 10-15 piglets per litter and ability to farrow two times per annum (Akinyosoye, 1999). These inherent and unique characteristics have made its production more economically viable compared to other farm animals.

These inherent qualities offer good incentives to boosting piggery enterprise so as to improve the economic status of the farmers as well as their 
nutritional wellbeing. Despite the economic leverage and nutritional advantages of pig, its production still remain the least when compared to other livestock sub-sector (poultry, goats, sheep and cattle) in the country in terms of meat supply (Central Bank of Nigeria, 2008). The current production of pig in Nigeria is 7.1 million compared to that of poultry (chicken), goat, sheep and cattle which are 145 million, 72.5 million, 41.3 million and 19.5 million respectively (National Agricultural Sample Survey, 2011). In spite of high demand and propensity for pork, research has shown that pig production in Nigeria is inadequate and thus requires drastic measures to ensure its economic improvement and sustainability.

When compared with poultry and other farm animals slaughtered and consumed daily in Nigeria, pigs represented less than $1 \%$ (FAO, 2006). This short fall in pig production could be attributed to some constraints in pig production which serve as disincentives; thus, leading to low productivity and profitability in pig production. Some of these constraints include inadequate capital, high cost of feeds, poor extension services, high cost of foundation stock, high cost of medication, disease outbreak, high wages and scarcity of skilled labour (Anukwu and Ebong, 2011). Thus, many farmers and investors are not willing to enter into pig production business and those who do enter tend to easily quit (Onah, 2015). Therefore, there is the need to increase pig production so as to expand the economic activities around the livestock subsector to narrow the animal protein deficit gap among Nigerian consumers and create more job opportunities among numerous job seekers in Udi Local Government Area (LGA) of Enugu State, Nigeria. Agada (2011) reveals that in spite of the quick return to capital in pig production, the enterprise is yet to take its rightful place in the livestock industry. The neglect or slow growth of the swine industry can be attributed to reasons which include religion, acceptability and above all management problems. Therefore, to reverse this situation in the study area, there is the need to critically evaluate the economics of piggery production in Udi LGA of Enugu State. There have been several studies on pig production in Nigeria, of which some focused on the characteristics and constraints of pig production in rural communities of Anambra State (Uneze and Onugu, 2012), economic efficiency of pig production in Oyo State, Nigeria (Adetunji and Adeyemo, 2012), socio-economic factors affecting pig production in Enugu state Nigeria (Machebe et al., 2009) and socioeconomic factors influencing swine management practices among women in Jamaia LGA in Kaduna State, Nigeria (Ajala et al., 2006). Though, Ogunniyi and Omoteso (2011) and Onah (2015) concentrated on the economic analysis of pig production performance and profitability in their studies in urban areas Oyo and Enugu States of Nigeria. Available literatures show that limited researches were conducted along the costs and determinants of net returns in pig enterprise especially in Udi LGA of Enugu State. Thus, the study tends to fill this gap in literature in the study area. Specifically, this study describes the socioeconomic characteristics of pig farmers in the LGA, estimated the costs and returns in pig production, examined the factors influencing net income from piggery enterprise in the study area and evaluated the problems faced by pig farmers in the area.

\section{MATERIALS AND METHODS}

The study area was Udi LGA, Enugu State of Nigeria. Udi comprises the 22 communities which include Akpakwume, Nze, Oghu, Awhum, Ebe, Abor, Ukana, Okpatu, Umulumgbe, Umuoka, Affa, Egede, Udi town, Obioma, Abia, Agbudu, Obinagu, Umuaga, Nachi, Amokwe, Eke and Ngwo. Udi LGA is bounded by the coordinates; latitude $6^{0} 19 ' \mathrm{~N}$ and $6^{\circ} 317^{\circ} \mathrm{N}$ of the equator and longitude $7^{0} 26 \mathrm{E}, 7.433^{\circ} \mathrm{E}$ of Greenwich meridian (Okorie, 2012). It is bounded on the North by IgboEtiti LGA, on the South by Enugu North LGA, on the East by Enugu East LGA and on the West by Ezeagu LGA all in Enugu State. Udi can be referred to as people living west of the Coal City, Enugu State. It has a population of 234,002 people (National Population Commission, 2006). The accessibility of Udi is easier because of the improved development and Urbanization in the area. It is accessible by road, air and mobile communication. $9^{\text {th }}$ Mile Corner in Udi serves as a major commercial centre in the local government.

The major source of income to the inhabitants of Udi LGA is predominantly agriculture. They are involved in agricultural activities such as cultivation of cassava, yams, cashew plantation, stringed beans, vegetables, oil beans, oil palm plantation, piggery, poultry, sheep and goat production. Palm wine tapping and marketing also constitute the major source of income to a portion of the population of the area.

Purposive and random sampling techniques were adopted in this study. Ngwo was purposively selected based on the large number of pig producers in the area. Five other communities were randomly selected from the remaining 21 communities; thus, six communities were involved in the study. Finally, 10 pig farmers were randomly selected from the list of pig farmers in each of the selected communities, giving 60 respondents for the study. Primary data were used for this study. The data were collected with the aid of a well structured and pretested questionnaire. The data were analysed using descriptive statistics such as mean, percentages, frequency counts and four point scale; gross margin, net farm income and inferential statistics such as ordinary least square regression analysis. 


\section{Model Specifications}

The ordinary least square (OLS) regression model was specified as follows:

$$
\begin{aligned}
& Y=\beta o+\beta_{1} X_{1}+\beta_{2} X_{2}+\beta_{3} X_{3}+\beta_{4} X_{4}+ \\
& \beta_{5} X_{5}+\beta_{6} X_{6}+\beta_{7} X_{7}+\beta_{8} X_{8}+\beta_{9} X_{9}+\mu
\end{aligned}
$$

where $Y$ is net Income from piggery enterprise ( $)$, $X_{1}$ is sex (Male 1, female 0), $X_{2}$ is age (years), $X_{3}$ is marital status (married 0, otherwise 1), $X_{4}$ is household size (number of persons), $\mathrm{X}_{5}$ is level of education attainment (years), $\mathrm{X}_{6}$ is cost of feeding (\#), $X_{7}$ is cost of labour ( $), X_{8}$ is occupation (farming 1 , otherwise 0 ), $X_{9}$ is farming experience (years), $\mu$ is error term, and $\beta$ is coefficient of explanatory variables.

The gross margin was specified as follows:

$$
\mathrm{GM}=\mathrm{TR}-\mathrm{TVC}
$$

where GM is gross margin, TR is total revenue, and TVC is total variable cost. The net farm income (NFI) or net income (NI) showing the profitability level was calculated to measure the operating efficiency of the enterprise or firm (Arene, 2008). The net profit margin was calculated as:

$$
\begin{aligned}
& \mathrm{NI}=\mathrm{TR}-\mathrm{TC} \\
& \mathrm{TC}=\mathrm{TVC}+\mathrm{TFC} \text { or NFI }=\mathrm{GM}-\mathrm{TFC}
\end{aligned}
$$

where NI is net income, TR is total revenue, TC is total cost, TFC is total fixed cost, TVC is total variable cost, GM is gross margin, and NFI is net farm income. Return on Invesment (ROI) was expressed as the ratio of NI to TC.

The straight line method of depreciation was used to compute the depreciated values of fixed assets in the piggery enterprise thus:

$$
\mathrm{D}=\frac{P-S}{n}
$$

where $\mathrm{D}$ is depreciation ( $\mathrm{N}$, $\mathrm{P}$ is purchase price $(\#), S$ is salvage value ( $), n$ is useful life of asset (number of years the equipment is used). The constraints faced by the pig enterprise were achieved using four point scale rating. The problems were categorized by the respondents as: very serious rated 4 ; serious rated 3 ; less serious rated 2; and not serious rated 1 .

From these values, a mean value $(\bar{x})$ was calculated as $(4+3+2+1=10 / 4=2.5)$. Using the interval scale of 0.05 , the upper cut-off limit was $2.5+0.05=2.55$ and the lower cut off limit was 2.5 $-0.05=2.45$. Based on this limits, any mean value that is above 2.55 was considered "very serious" and mean values below 2.45 was considered "not serious" while mean values between 2.45 and 2.55 were considered serious (Ukwuaba et al., 2018).

\section{RESULTS AND DISCUSSION}

\section{Socioeconomic Characteristics of Pig Farmers}

Table 1 shows that majority $(85.0 \%)$ of the farmers were male while $15.0 \%$ of the farmers were female. This implies that pig farming in Udi LGA of Enugu State is dominated by male. The result could be as a result of few females being unable to bear the stress and the demanding nature of commercial pig production in the area. The result agrees with Uneze and Onugu (2012) who reported larger proportions $(55.0 \%)$ and $(63.3 \%)$ of male in pig production in both Abia and Anambra States, respectively.

Majority $(88.7 \%)$ of pig farmers in the study

\begin{tabular}{|c|c|c|c|}
\hline $\begin{array}{l}\text { Socio-economic } \\
\text { variables }\end{array}$ & $\begin{array}{l}\text { Frequency } \\
(60)\end{array}$ & $\begin{array}{c}\text { Percentage } \\
(\%)\end{array}$ & Mean \\
\hline \multicolumn{4}{|l|}{ Sex } \\
\hline Female & 9 & 15.0 & \\
\hline Male & 51 & 85.0 & \\
\hline Age & & & 48 \\
\hline $21-30$. & 5 & 8.4 & \\
\hline $31-40$ & 14 & 23.3 & \\
\hline $41-50$ & 11 & 18.5 & \\
\hline $51-60$ & 17 & 28.5 & \\
\hline $61-70$ & 11 & 18.5 & \\
\hline $71-80$ & 2 & 3.3 & \\
\hline \multicolumn{4}{|l|}{ Marital status } \\
\hline Single & 7 & 11.06 & \\
\hline Married & 49 & 81.70 & \\
\hline Widowed & 4 & 6.70 & \\
\hline Household size & & & 5 \\
\hline $1-5$ & 37 & 63.33 & \\
\hline $6-10$ & 23 & 36.67 & \\
\hline \multicolumn{4}{|l|}{ Education } \\
\hline Primary & 22 & 36.70 & \\
\hline Secondary & 20 & 33.30 & \\
\hline Tertiary & 18 & 30.0 & \\
\hline \multicolumn{3}{|c|}{ Farming experience (years) } & 11.47 \\
\hline $1-5$ & 30 & 50.0 & \\
\hline $6-10$ & 18 & 28.40 & \\
\hline $11-15$ & 7 & 11.8 & \\
\hline $16-20$ & 3 & 5.0 & \\
\hline $21-25$ & 2 & 3.30 & \\
\hline $26-30$ & 1 & 1.70 & \\
\hline \multicolumn{4}{|c|}{ Secondary occupation } \\
\hline Farming & 16 & 26.70 & \\
\hline Trading & 8 & 13.30 & \\
\hline Civil servant & 13 & 21.30 & \\
\hline Artisan & 21 & 35.00 & \\
\hline Student & 2 & 3.30 & \\
\hline \multicolumn{4}{|l|}{ Source of capital } \\
\hline Relations & 3 & 5.0 & \\
\hline Personal Savings & 53 & 88.3 & \\
\hline Cooperatives & 3 & 5.0 & \\
\hline Agricultural Bank & 1 & 1.7 & \\
\hline \multicolumn{4}{|l|}{ Breed Reared } \\
\hline land race & 2 & 3.3 & \\
\hline Hampshire & 1 & 1.7 & \\
\hline Crosses & 57 & 95.0 & \\
\hline
\end{tabular}
area falls within the age range of 31 to 60 . The mean age of the farmers was 48 , implying that the pig farmers were in the economically active age. The results showed that the pig farmers were young

Table 1: Socioeconomic characteristics of the respondents 
and energetic and thus can bear the stress and demanding nature of the enterprise. The result is in accordance with Anyanwu et al. (2001) who reported that people aged 40-50 years are more energetic and have the capacity to use new technologies and innovations.

With respect to household size, the result showed that the modal household size range was 1 to 5 while the mean household size of the pig farmers was five persons. This implied that the family members could serve as source of labour and this would help in reducing the cost of hiring labour. This result agrees with Okoedo-Okojie (2015) which indicated a mean household size of six persons among pig farmers in Delta State, Nigeria.

The results in Table 1 also show that majority (95\%) of the respondents had crossed breeds of pigs while $3.3 \%$ and $1.7 \%$ said they rear pure breeds of landrace and Hampshire. Thus, observations made on the farms showed that the herd structure comprised piglets, growers, sows and boars.

The marital status of pig farmers in the study area showed was shown in Table 1 . It indicated that majority $(81.7 \%)$ of the respondents were married, about $12 \%$ single while $(6.7 \%)$ were widowed. The high level of married population could be a way of increasing household size to assist in the day today running of the enterprise as well as to assist in other activities carried out in the farm. The high percentage of married respondents conforms to Jibowo (2012) who reported that majority of the adult population of a society consists of married people. Ani (2015) opined that marriage has a direct relationship with family stability; therefore the high percentage of married respondents suggested that the pig farmers were stable and able to make good business decisions. The result also implied that spouses largely help in family labour for light farm operations (Ogunniyi and Omoteso, 2011).

Table 1 further shows that about $37 \%$ of the respondents had only primary education, $33.3 \%$ attended secondary education while $30 \%$ had tertiary education. This shows that there is high literacy level among the respondents which implied that pig farming requires certain level of education in terms of management to ensure productivity. The higher the literacy level of an individual, the more skilled the individual is, and the more effective is the managerial abilities. The result is consistent with Kim and Wade (2015), who reported that education is vital for the management and expansion of any enterprise. The higher the literacy level of an individual, the more skilled the individual is, and the more effective is the managerial abilities.

The years of farming experience of the respondents as shown in Table 1 reveal that $50 \%$ of the respondents had between 1 and 5 years of experience while only $1.7 \%$ had between 26 and 30 years of experience respectively. The mean farming experience was 11.47 years, implying that the enterprise was relatively new in the area. This could be attributed to environmental pollution common in pig framing. It could also be pointer to the fact that many find it cumbersome, too demanding and capital intensive. Chukwuji (2006) noted that success and stability of any business depends on the skill and experience of the manager, while Ugwumba (2010) and Ijeoma (2012) opined that education and experience are veritable tools for acquiring new ideas and skills that reflect positively on scope of enterprising, income and profit.

The results in Table 1 also show that majority of the pig farmers had other occupation other than pig farming. About $27 \%$ of them are engaged in crop farming, another $13.30 \%$ are involved in trading while 35 and $3.30 \%$ were artisans and students, respectively. That majority of respondents are engaged in other occupations could be a sort of shock absorber or insurance in time of losses in pig production or a way of diversification of enterprise. This is advisable especially in this period of economic recession so as to meet up with family expenses and improve the living conditions of the family. This finding is in tandem with Ajala et al. (2006) that majority $(81.1 \%)$ of pig farmers in Jamaia LGA in Kaduna State had other occupation, such as crop farming, civil service, and trading.

The source of capital in any farming enterprise is very important. In this regard, Table 1 shows that $88.3 \%$ of the respondents sourced their capital from personal savings while 5.0, 5.0 and $1.7 \%$ sourced theirs from relatives, cooperative society and agricultural banks, respectively. The result agrees with Adekunle and Ajani (1999) who found that the source of capital of livestock farmers was either from friends and relatives or from their personal savings, which mostly comprised of retained profits made from previous earnings. However, some respondents sourced their capitals in form of loans from cooperatives and agricultural banks. Financial institutions such as microfinance and the commercial banks contributed very little to the start up funds in the study area, this is not much surprising considering the risky nature of agriculture which deters banks and other investors from lending money to farmers.

Table 2: The regression results showing factors influencing net income from piggery enterprise

\begin{tabular}{lccc}
\hline Variables & Coefficient & T- value & Std error \\
\hline (Constant) & 0.078 & 0.852 & 0.091 \\
sex & -0.112 & -1.389 & 0.081 \\
age & -0.035 & -0.351 & 0.099 \\
marital status & 0.031 & 0.345 & 0.089 \\
level of education & $-0.271 *$ & -2.751 & 0.098 \\
household size & 0.145 & 1.403 & 0.103 \\
farming experience & 0.080 & 0.803 & 0.099 \\
primary occupation & 0.060 & 0.746 & 0.080 \\
cost of feed & $0.687 * *$ & 6.054 & 0.113 \\
cost of labour & $0.329 *$ & 3.284 & 0.100 \\
\hline $\mathrm{R}^{2}=0.864 ; * *, *=$ significant at $P \leq 1 \%$ and 5\% respectively.
\end{tabular}




\section{Factors Affecting the Net Farm Income of the Pig Farmers}

An econometric method of ordinary least square (OLS) regression model was employed in the test for the factors that affect the net income of pig farmers in the study area. The variables tested included cost of labour, marital status, primary occupation, sex, age, level of education, farming experience, household size and cost of feed.

The factors that were identified to affect the net income of pig farmers in the study area are presented in Table 2 . The $\mathrm{R}^{2}$ value of 0.748 shows that the explanatory variables explained up to $74.8 \%$ of the variations in the income of farmers. Thus, the remaining $25.2 \%$ could be due to other factors not accounted for by the model. Three independent variables (level of education $(-0.271)$, cost of feed (0.689) and cost of labour (0.329) were statistically significant and thus exerted influence on pig farmers' farm revenue. This implied that the three factors were among the major determinants of pig farmers' revenue in the study area.

The result of the factors influencing the net income of the pig farmers resonate with those of other studies in Nigeria; Ibitoye et al. (2016), Onah (2015), Adetunji and Adeyemo (2012), Machebe et al. (2009) who indentified the level of education, cost of feeds and labour, farming experience and age among other variables as significant factors influencing the net farm income of pig farmers in the various studies across Nigeria. The coefficient of level of education was negative $(-0.271)$ and statistically significant at $5 \%$ level of probability. The sign of the variable is at variance with apriori expectation. The result implied that a unit increase in the educational level of the pig farmers decreased the net income by 0.271 units. The result could be attributed to the fact that as a farmer becomes more educated, the attention and seriousness given to the pig production would reduce, thereby leading to loss of attention and interest given to the piggery enterprise and consequently, reduction in income level.

The above observation is not surprising as it is evidenced in Table 2 which shows that majority of the pig farmers attended formal education and therefore are involved in other jobs that make them pay less attention to their pig enterprise. This is justifiable as more educated people are involved in white collar jobs, and thus would pay less attention to the pig farming. This result disagrees with Nwankwo (1999) that the level of educational attainment is likely to affect the degree of one's business alertness and ability to seize business initiatives and advantages, hence increased income. Also, the result contradicts the findings of Agbo and Usoroh (2015) and Ibitoye et al. (2016) who reported that education was positively related to the net income of shrimp marketers and pig farmers in Akwa Ibom and Kogi States, Nigeria respectively.
Conversely, the cost of feed had a positive (0.687) relationship with net farm income generated from the piggery business and was statistically significant at 5\% level of probability. This implies that a unit increase in the cost of feed will increase the farmers' farm income by 0.687 units and vice versa. Also cost of labour had a direct (0.329) relationship with the net farm income of the pig farmers. This is an indication that a unit increase in cost of labour will increase the farmers' income by 0.329 units while a unit decrease will lead to a reduction of the income by 0.329 units. Therefore, the result implied that, high costs of feed and that of labour in the study area led to higher revenue of the farmers in the study. By implication; high cost of labour and feeds connote higher scale of production i.e. having more farm workers attending to higher number of pigs and consequently, resulting in higher farm income.

\section{Cost and Returns of Pig Enterprise}

The profitability of pig enterprise in this study was assessed using gross margin and net income for profitability in terms of sales and net return on investment. The estimated profitability for pig production enterprise in the study area was shown in the Table 3. The total variable cost (TVC) and the total fixed cost (TFC) were $811,236.70$ $(\$ 2,233.33)$ and $\$ 76,592.88$ (\$210.86) respectively for a production cycle of 12 months. This gives rise to total cost (TC) of 887,828.95, (\$2444.19) of pig production in the area per annum. On the other hand, the sources of revenue in piggery enterprises were sales from piglets $\$ 79,434.78$ (\$218.68), growet $\$ 1,084,444.00 \quad(\$ 2,985.47)$, finisher $\$ 437,810.30 \quad(\$ 1,205.29)$ and piggery manure $\$ 33,942.86$ (\$93.44). Thus, the total revenue generated was of $\$ 1,635,632 \quad(\$ 4,502.89)$ per production cycle. The gross margin (GM) was $\$ 824,395.30$ (\$2,269.56) while the net farm income was $\$ 747,797.42$ (\$2058.68). The result shows that the enterprise was profitable as indicated by the income above fixed cost was positive.

The findings were in agreement with Onah (2015) who found that the mean profit margin of pig production in Enugu metropolis was $\$ 3,689,267.98$ (\$10,177.37) per year. It also resonates with the study of Oni (2014) in western part of Nigeria in which he reported $\$ 233,007.50$ (\$642.78) and $\$ 147,857.50(\$ 407.88)$ as the gross margin and net farm income of a pig farm per annum respectively. The result is also consistent with the findings of Ibitoye et al. (2016) who reported an annual gross margin of $\$ 44,171$ (\$121.60) for pig producers in Kogi state, Nigeria. Also; the result on return on investment of 0.84 , which implied that for every naira invested in pig enterprise, $¥ 0.84$ kobo was received as profit by the producers further confirmed the profitability of pig production in Udi LGA of Enugu state, Nigeria. 
Table 3: Cost and returns of piggery enterprise

\begin{tabular}{|c|c|c|}
\hline Cost item & Amount & Percentage $(\%)$ \\
\hline Variable cost (VC) & 183831.70 & 22.66 \\
\hline Cost of feed & 133056.80 & 16.40 \\
\hline Palm kernel cake & 10080.00 & 1.24 \\
\hline Spent grain & 14555.56 & 1.79 \\
\hline Bambara nut chaff & 141570.00 & 17.45 \\
\hline Cost of transportation & 11775.51 & 1.45 \\
\hline Cost of fuel & 4925.81 & 0.61 \\
\hline Cost of water & 10897.37 & 1.35 \\
\hline Cost of veterinary services & 116350.00 & 14.35 \\
\hline Cost of drugs & 13473.91 & 1.66 \\
\hline Cost of labour & 5700.00 & 0.70 \\
\hline Repair/maintenance cost & 165000 & 20.34 \\
\hline Cost of piglet booster & 811236.7 & \\
\hline Interest on loan & 26259.00 & 34.28 \\
\hline Total variable cost (TVC) & 261.90 & 0.34 \\
\hline Fixed cost $(\mathrm{FC})$ & 8624.87 & 11.26 \\
\hline Cost of building & 121.37 & 0.16 \\
\hline Cost of wheel barrow & 102.70 & 0.13 \\
\hline Cost of water tank & 98.18 & 0.12 \\
\hline Cost of shovels/spade & 85.12 & 0.11 \\
\hline Cost of basins/buckets & 93.20 & 0.12 \\
\hline Cost of head pans & 125.32 & 0.16 \\
\hline Cost of brooms & 321.22 & 0.41 \\
\hline Cost of rake & 40500.00 & 52.87 \\
\hline Cost of matchet & 76592.88 & \\
\hline Cost of jerry can/gallons & 887828.95 & \\
\hline Cost of farm van & 79434.78 & 4.86 \\
\hline Total fixed cost (TFC) & 1084444.00 & 66.30 \\
\hline Total cost (TC) & 437810.30 & 26.77 \\
\hline \multicolumn{3}{|l|}{$=\mathrm{TFC}+\mathrm{TVC}$} \\
\hline Revenue items & 33942.86 & 2.07 \\
\hline Sales of piglets & \multicolumn{2}{|l|}{1635632} \\
\hline Sales of grower & \multicolumn{2}{|c|}{$(1635632-811236.7)=824395.3$} \\
\hline Sales of finisher & \multicolumn{2}{|c|}{$(824395.3-76597.88)=747797.42$} \\
\hline Sales of pig manure & \multicolumn{2}{|c|}{$(747797.42 / 887828.95)=0.84$} \\
\hline \multicolumn{3}{|l|}{ Total revenue (TR) } \\
\hline \multicolumn{3}{|c|}{ Gross margin $(\mathrm{GM})=\mathrm{TR}-\mathrm{TVC}$} \\
\hline \multicolumn{3}{|c|}{ Net farm income $(\mathrm{NFI})=\mathrm{GM}-\mathrm{TFC}$} \\
\hline \multicolumn{3}{|c|}{ Return on investment $(\mathrm{ROI})=\mathrm{NFI} / \mathrm{TC}$} \\
\hline
\end{tabular}

\section{Problems Faced by Pig Farmers}

The obstacles identified as militating against smooth running of the piggery enterprise in the study area are presented in Table 4. The major constraints identified as the hindrances to the optimum production of the piggery enterprise were high cost of animal feeds $(\bar{x}=3.8)$, huge capital requirement $(\bar{x}=3.6)$, inadequate livestock extension services $(\bar{x}=3.0)$, high cost of veterinary drugs $(\bar{x}=3.0)$ poor feeding system $(\bar{x}=2.8)$, diseases/parasites infestation $(\bar{x}=2.7)$, poor management $(\bar{x}=2.7)$, poor housing $(\bar{x}=2.6)$, poor agricultural research on pigs $(\bar{x}=2.6)$, insufficient credit facilities and subsidies ( $\bar{x}=2.8)$, low application of modern and innovative production system $(\bar{x}=2.9)$.

Capital being one of the major constraints was not surprising, considering the current battered state of the economy which has led to the general increase in inputs of piggery enterprises., accessing credits from commercial or even agricultural specialized banks has become increasingly difficult to the pig farmers due largely to the high interest rate charged by these banks and huge collateral requirements. This is line with the findings of Ajala et al. (2006), Adetunji and Adeyemo (2012) and
Table 4: Constraints faced by pig farmers

\begin{tabular}{lcl}
\hline Problems & Mean value & Decision \\
\hline Poor housing & 2.6 & Very Serious \\
Inadequate livestock extension & 3.0 & Very Serious \\
and farmer education services & & \\
Ignorance of right feeding system & 2.8 & Very Serious \\
High cost of animal feeds & 3.8 & Very Serious \\
$\begin{array}{l}\text { Diseases \& parasites infestation } \\
\text { Huge capital requirement }\end{array}$ & 2.7 & Very Serious \\
Poor farm management & 3.6 & Very Serious \\
Poor agricultural research on & 2.7 & Very Serious \\
pigs and pig production & 2.6 & Very Serious \\
High cost of veterinary drugs & 3.0 & Very Serious \\
Insufficient credit facilities & 2.8 & Very Serious \\
and subsidies & & \\
Low application of modern and & 2.9 & Very Serious \\
innovative production & & \\
Technologies in pig farming & 2.9 & Very Serious \\
Scarcity of water during dry season & 2.6 & Very Serious \\
High mortality & 2.7 & Very Serious \\
Cannibalism & 2.6 & Very Serious \\
\hline Souce: Field Survey, 2017 & &
\end{tabular}

Source: Field Survey, 2017

Onah (2015) who indicated that lack of capital and poor access to credit facilities as the major constraints to pig enterprise in their studies. The poor state of extension services, poor agricultural research and low application of modern production system could be attributed to negligence on the part of government, that tend to pay lip services to the growth of agriculture. This is as authenticated by the consistent poor and lean Nigeria government budget for agriculture, which is considered as one of the lowest in Africa. It could also be blamed on high level of negligence on the part of extension workers lack motivation and due to poor remunerations and have failed to discharge their duties with dispatch. The result was corroborated by the findings of Ibitoye et al. (2016) and Uneze and Onugu (2012) who indicated that inadequate extension services and education as well as outdated production system and technologies are the major hindrance to pig production in Anambra and Kogi states respectively. The problems of disease and parasite infestation, cannibalism, infant mortality could be attributed to poor housing, poor feeding system and general poor farm management. The result is in resonance with the findings by Abonyi et al. (2012) which showed that about $12 \%$ of piglets were cannibalized by older pigs; this was attributed to inappropriate farm structures and improper management practice.

\section{CONCLUSION}

Piggery enterprise in Udi LGA of Enugu State is dominated by the educated, married males who are experienced in the enterprise. Only few youths and young graduates were involved in the piggery business. The enterprise is profitable and viable as suggested by the results of gross margin, net farm income and return on investment. The level of education cost of feed and cost of labour had significant effect on the revenue generated from pig production. Huge capital investment requirement, high cost of veterinary services, insufficient credit 
facilities and subsidies, poor extension services low application of modern and innovative production systems among others were the major problems faced by the pig farmers in the study area. The study recommends that the government and other relevant agencies should provide subsidies on vaccines, make credit facilities available and accessible to pig farmers, as well as the provision of veterinary and extension services especially in the areas of good farm management, innovations and modern technologies in pig farming.

\section{REFERENCES}

Abonyi F.O., Omeh C.V.O. and Machebe N.S. (2012). Neonatal mortality of pigs in Nsukka, Southeast Nigeria. African J. Biotechnol, 11 (68), 13228-13234

Adekunle O.A. and Ajani O.I. (1999). Economic of beef marketing in Bodija market in Ibadan North Local Government Area of Oyo State. Tropical Journal of Animal Science, 1(1), 93-100

Adetunji M.O. and Adeyemo K.E. ( 2012). Economic efficiency of pig production in Oyo State, Nigeria: A stochastic production frontier approach. American Journal of Experimental Agriculture. 2 (3), 382-394

Agada E.S. (2011). Economic Analysis of Swine Production: A Study of Two Local Government Area of Kaduna State, Nigeria. MSc Thesis, Department of Agricultural Economics \& Farm Management, University of Ilorin, Nigeria

Agbo F.U. and Usoroh B.A. (2015). Marketing of estruine shrimps in Awka Ibom State, Nigeria. Journal of Marketing and Consumer Research, 15 (7), 63-70

Ajala M., Adesehiwa A.O.K. and Bawa G. (2006). Socioeconomic factors influencing swine management practices among women in Jamaia, Local Government Area in Kaduna State, Nigeria. Tropical \& Subtropical Agroecosystems, 6 (2), 43-48

Akinyosoye V.O. (1999). Senior Tropical Agriculture. Ibadan: Macmillan Nigeria Ltd

Ani D.P. (2015). Market Integration and Pricing Efficiency of Soybeans in Benue and Enugu States, Nigeria. PhD Thesis, Department of Agricultural Economics, University of Nigeria, Nsukka

Anukwu M.I. and Ebong V.O. (2011). Analysis of the performance of piggery loan beneficiaries in the integrated farmers' scheme of Akwa Ibom State: A case of Uyo Agricultural Zone. Nigerian J. Agric., Food Environ. 7 (3), 73-79

Arene C.J. (2008). Economic Analysis of Agricultural and Rural Development Projects ( $2^{\text {nd }}$ Ed.), Enugu: Prize Publishers

Central Bank of Nigeria (2008). CBN report and statement of accounts 2003-2007. CBN Publications

Chukwuji C. (2006). Factor Productivity and Technical Efficiency in Cassava Based Food Crop Production System in Delta State, Nigeria. MSc Thesis, Department of Agricultural Economics \& Extension, Delta State University, Abraka, Nigeria

FAO (2006). Animal production and consumption indices in Africa. Food and Agricultural Organization (FAO) Rome, Italy
Ibitoye S.J., Shaibu U.M., Sanda M.E. and Oshadare D. (2016). Economic analysis of local swine production amond small scale farmers in Kabba/Bunu Local Government Area of Kogi State, Nigeria. Gashua J. Irrig. \& Desertification Studies, 2 (2), 2489-2494

Ijeoma J. (2012). Adoption of improved snail production techniques by farmers in Ohafia agricultural zone, Abia State, Nigeria. In: Aniebo A. \& Ugwumba C.O.A. (Eds.), Int. Agric. Conf., ANSUISAC, Nigeria, pp. 156-167

Jibowo A.A. (2012). Essentials of Rural Sociology. Abeokuta: Gbemi Sodipo Press Ltd

Machebe N.S., Onyekuru N.A. and Ekweogu N. (2009). Socio-economic factors affecting pig production in Enugu State Nigeria. J. For. Soc. Sci., 7 (1), 450-455

National Agricultural Sample Survey (2011). Federal Ministry of Agriculture, Water Resources and Rural Development, Abuja

National Population Census (2006). Nigerian Census Figures for Thirty-Six States of Nigeria and Federal Capital Abuja

Nwankwo H.M. (1999). Impact of community banks in financing agricultural production in Abia State: A case study of Umuariaga community bank, Ikwuano LGA Abia State, Nigeria. PGD Research Report of College of Agriculture, Abia State University, Uturu, Nigeria

Ogunniyi L.T. and Omoteso O.A. (2011). Economic analysis of swine production in Nigeria: A case study of Ibadan Zone of Oyo State. J. Human Ecol., 35 (2), $137-142$

Okoedo-Okojie D.U. (2015). Assessment of group teaching methods effectiveness in dissemination of swine technologies among farmers in Delta State, Nigeria. Nigerian J. Agric. Food Environ., 11 (2), 14-19

Okorie O.J. (2012). Level of Adoption of Improved Cassava Varieties and the Profitability of Cassava Production in Enugu State, Nigeria. MSc Thesis, Department of Agricultural Economics, University of Nigeria, Nsukka

Onah F.C. (2015). Analysis of Production Performance and Profitability of Pig Farms in Enugu State, Nigeria. MSc Dissertation, Department of Agricultural Education, University of Nigeria, Nsukka

Oni O.A. (2014). Economic Analysis of Pig Production in Orire Local Government Area of Oyo State. MSc Dissertation, Department of Agricultural Economics \& Extension, Ladoke Akintola University of Technology, Ogbomoso, Oyo State, Nigeria

Uneze C.U. and Onugu C.U. (2012). Characteristics and constraints of pig production in rural communities of Anambra State, Nigeria. Proc. 26th Annual Conf. of the Farm Management Association of Nigeria (FAMAN), pp. 450-455

Ugwumba C.O. (2010). Analysis of the agribusiness of catfish marketing for poverty alleviation and women empowerment in Anambra, State. In R. Okoh (ed.), Nigeria Engendering Policy for Attainment of Millennium Development Goals (pp. 89-98.). Asaba, Nigeria: 1st Annual National Conference of Centre for Human Research and Gender Services

Ukwuaba I.C., Agbo F.U. and Adeosun K.P. (2018). Socio-economic and institutional determinants of watermelon marketing in Enugu state, Nigeria. $J$. Agric. Ext., 22 (3), 161-173 